\title{
Enrichment on quality of aonla (Emblica officinalis G.) fruit bars by blending
}

\author{
Deepika and Payel Panja* \\ Department of Post-Harvest Technology of Horticultural Crops, Bidhan Chandra Krishi Viswavidyalaya, Mohanpur, \\ Nadia -741252 (West Bengal), INDIA \\ *Corresponding author. E-mail: payel.panja06@gmail.com
}

Received: May 14, 2016; Revised received: September 25, 2016; Accepted: January 16, 2017

\begin{abstract}
The main objective of the study was to standardize enrichment of aonla pulp to develop fruit bars. The experiment was laid out in Completely Randomized Design (CRD) with 10 treatments. Aonla pulp was blended with 25 to $75 \%$ of different fruit (mango, papaya and jackfruit) pulp viz. Aonla pulp, Aonla with mango, papaya and jackfruit in different proportion of 3:1, 1:1 and 1:3 each fruit respectively. The initial moisture content was higher in aonla pulp enriched with mango pulp in 1:3 proportions. Enrichment of aonla pulp with fruit pulp of mango, papaya and jackfruit reduced the ascorbic acid, titratable acidity and tannin content of the resultant fruit bars compared to that from pure aonla pulp, which is an indication in the reduction of astringency. Enrichment also resulted in an increase in total soluble solids, reducing, non-reducing and total sugars of the resultant fruit bars. Enrichment of aonla pulp with fruit pulp of provitamin A rich fruits like mango, papaya and jackfruit showed a rise in total carotenoids and reduced astringency and acidity, thereby resulting in fruit bars with altered palatability and enhanced nutrition. Enriched fruit bars contained three vital antioxidants viz. Vitamin C, carotenoids and polyphenols of all the treatments, enriched fruit bar containing $25 \%$ aonla and $75 \%$ mango $\left(\mathrm{T}_{4}\right)$ was found superior in organoleptic evaluation.
\end{abstract}

Keywords: Aonla, Fruit bar, Nutritional properties, Sensory evaluation

\section{INTRODUCTION}

Aonla (Emblica officinalis G.) is valued for its nutritional qualities and pharmacological properties which belongs to the family Euphorbiaceae. It is a store house of vital antioxidants like ascorbic acid, polyphenols and is also a rich source of minerals like $\mathrm{Fe}, \mathrm{Ca}, \mathrm{K}$ etc. (Jain and Khurdiya, 2002). These qualities of aonla are utilized in the Ayurvedic and Unani systems of medicines, curing common cold, gastric troubles, acidity and scurvy (Tandon et al., 2003), bronchitis, diabetes, diarrhoea, jaundice and dyspepsia (Bhosale et al., 2000). It has proven to possess immensely high amount of nutritional benefits as well as therapeutic properties, but still regarded as a minor and under exploited fruit crop. The fruits are the second richest source of vitamin $\mathrm{C}$ among fruits after Barbados cherry (Malpighia glabra L.) (Singh et al., 2006). Due to high acidity and astringency, the fruit is not to be relished in the fresh form. Aonla fruits can be used either fresh or in powdered form in various preparations like Triphala, Arishtha, Chyavanprash etc. The fruit is a potent antioxidant, antimicrobial (Ahmad et al., 1998), hypolipidemic, antibacterial, anti-tumour (Jose et al., 2001) antiviral, antacid, antidiabetic, anti-ulcerogenic activities etc. (Khopde et al., 2001; Sairam et al., 2002).

India is blessed with a variety of agro-climatic conditions and therefore, our country produces a wide range of tropical, subtropical, temperate and arid zone fruits. Many minor fruits like aonla, bael, jamun, tamarind etc. are extensively cultivated in the arid zones of our country. Limited availability and high perishability are two major bottlenecks that demand its immediate postharvest utilization. In spite of the rapid strides made in the release of new varieties and expansion of area under cultivation, considerable losses are encountered in aonla due to lack of suitable post-harvest management practices. The fruit cannot be stored beyond a week under ambient storage conditions. Therefore, suitable innovative techniques in packaging and storage are required to prolong the availability of this fruit. (Kirtikar and Basu, 1993). Diversification of processed products of aonla with altered palatability and enhanced nutrition has been attempted to make them available throughout the year. However, excellent nutritive, antioxidant and therapeutic values of the fruit can be tapped for developing good quality products. Value added products can be prepared from aonla fruit by converting it into various processed products by employing different methods of preservation (Kadam, 2001). Hence the present study deals with the preparation of a novel, value added and nutritious product from aonla. A suitable technique for enrichment in the development of fruit bars from aonla, with fruits that are good sources of provitamin A will result in enhanced nutrition and altered palatability. 


\section{MATERIALS AND METHODS}

Experimental site: The present investigation on enrichment of aonla pulp to form fruit bars were carried out under laboratory condition in the Department of Processing Technology, Kerala Agricultural University in the year 2013-14.

The experiment was carried out with aonla fruits of the local variety and fruits of papaya (Red Lady), jackfruit (Then Varikka) and mango (Bangalora) were procured from the fruit market, Thrissur.

Preparation of fruit bars from pure aonla pulp and blended pulp: Fruit bars were prepared from pure aonla fruit and also from blended fruit pulp in which pulp of aonla was mixed in different ratios with mango (Mangifera indica), papaya (Carica papaya) and jackfruit (Artocarpus heterophyllus) pulp. The fruit pulp thus prepared was mixed with powdered cane sugar, which was ground in a grinder. The total soluble solids content of the pulp was raised to $35^{\circ}$ Brix and the acidity of the pulp was adjusted to 0.6 per cent. Clean stainless steel trays, smeared with vegetable oil were taken and the prepared pulp was spread on these trays to a thickness of $10 \mathrm{~mm}$. These trays were loaded into a cabinet drier maintained at $58 \pm 2{ }^{\circ} \mathrm{C}$. The pulp was dried to a thickness of $5 \mathrm{~mm}$. After drying to optimum moisture content, the dried pulp was cut into bars.

\begin{tabular}{ll}
\hline Treatments & Preparation of fruit bars \\
\hline $\mathrm{T}_{1}$ & Aonla pulp $(100 \%)$ \\
$\mathrm{T}_{2}$ & Aonla $(75 \%)+$ Mango $(25 \%)$ \\
$\mathrm{T}_{3}$ & Aonla $(50 \%)+$ Mango $(50 \%)$ \\
$\mathrm{T}_{4}$ & Aonla $(75 \%)+$ Mango $(75 \%)$ \\
$\mathrm{T}_{5}$ & Aonla $(50 \%)+$ Papaya $(25 \%)$ \\
$\mathrm{T}_{6}$ & Aonla $(25 \%)+$ Papaya $(75 \%)$ \\
$\mathrm{T}_{7}$ & Aonla $(50 \%)+$ Jackfruit $(25 \%)$ \\
$\mathrm{T}_{8}$ & Aonla $(25 \%)+$ Jackfruit $(50 \%)$ \\
$\mathrm{T}_{9}$ & \\
$\mathrm{~T}_{10}$ &
\end{tabular}

Physico- chemical characteristics of fruit bar viz: Total soluble solids (TSS) were estimated by hand refractometer $\left(0-32^{\circ} \mathrm{B}\right)$. The readings obtained were calibrated against a standard temperature at $20^{\circ} \mathrm{C}$ as per the International Temperature Correction Table and expressed as ${ }^{\circ}$ Brix. The moisture content was determined by drying a known weight of the sample at 50 $-60{ }^{0} \mathrm{C}$ to a constant weight and expressed as per cent (Ranganna, 1997). Acidity and ascorbic acid were determined by standard method (AOAC, 1990) and results were expressed as percentage citric acid and $\mathrm{mg} / 100 \mathrm{ml}$ of juice respectively. Total sugars, reducing and non-reducing sugars were estimated by the Lane and Eynon volumetric methods (AOAC, 1990). Tannin content was determined by colorimetric method (Ranganna, 1997) using a standard curve of tannic acid. Total carotenoids were measured by spectrophotometer (Ranganna, 2000).
Sensory evaluation: The products were judged by a panel of judges of different age groups for appearance, colour, flavour, texture, odour, taste, after taste and overall acceptability, based on a 9 point hedonic scale rating (Amerine et al., 1965). A score of 5.5 and above was considered acceptable

Statistical analysis: Observations under each experiment were tabulated and analyzed statistically in a completely randomized design (CRD) as proposed by Panse and Sukhatme (1976). The treatments were ranked according to Duncan's Multiple Range Test (DMRT) as suggested by Duncan (1955). Data pertaining to organoleptic evaluation were analysed using Kendall's coefficient of concordance.

\section{RESULTS AND DISCUSSION}

Sensory evaluation: Based on the results obtained from sensory evaluation of fruit bars, best treatment was selected in accordance with the maximum score obtained for fruit bar from each combination of enrichment (Table 1). Increase in the proportion of fruit pulps of mango, papaya and jackfruit in aonla pulp in the preparation of enriched fruit bars resulted in higher scores for sensory properties. Significant differences among various treatments with respect to colour and appearance scores of aonla fruit bars were observed. $\mathrm{T}_{4}$ (16.90) and $T_{7}$ (16.70) respectively had the highest sensory score, which might be due to permeation of higher amount of sugar in mango and papaya in aonla bars, which improved the colour and appearance. In texture, $\mathrm{T}_{7}(7.50)$ and $\mathrm{T}_{3}(6.80)$ got the highest sensory score, which may be due to enough moisture content in these fruits providing appropriate softness to the samples. $\mathrm{T}_{4}$ had the highest sensory score in flavor (8.70), odour (8.40) and taste (9.05), respectively. Of all the treatments, enriched fruit bar containing $25 \%$ aonla and $75 \%$ mango $\left(\mathrm{T}_{4}\right)$ scored the highest values (8.60) for overall acceptability, which was on par with the treatment $\mathrm{T}_{7}(25 \%$ aonla $+75 \%$ papaya $)$ which had a score of 8.55 . This could be due to better colour and appearance, texture and taste obtained by preparation of fruit bars with different fruits. Enrichment of aonla with jackfruit, in the preparation of fruit bar, was found inferior, based on scores observed in the organoleptic evaluation compare with the other product like blended with mango and papaya.. Fruit bar prepared from pure aonla pulp was also found unacceptable to the panel of judges because of its highly acidic and astringent nature.

Physicochemical characteristics of the aonla fruit bars moisture: The moisture content of the bars was recorded immediately after preparation The result revealed that the treatment $\mathrm{T}_{4}(25 \%$ aonla $+75 \%$ mango) had the highest moisture content $(17.17 \%)$ and the lowest moisture content $(13.23 \%)$ was observed in the treatment $\mathrm{T}_{1}(100 \%$ aonla $)$. This might be due to hygroscopic nature of sucrose and 
Table 1. Mean sensory scores for the pure and enriched aonla fruit bars.

\begin{tabular}{lccccccccc}
\hline Samples & Appearance & Colour & Flavour & Texture & Odour & Taste & After taste & $\begin{array}{c}\text { Overall } \\
\text { acceptability }\end{array}$ & $\begin{array}{c}\text { Total } \\
\text { score }\end{array}$ \\
\hline $\mathrm{T}_{1}$ & 6.40 & 3.95 & 3.80 & 4.70 & 4.50 & 6.50 & 3.55 & 4.35 & 37.75 \\
$\mathrm{~T}_{2}$ & 4.65 & 4.95 & 5.00 & 5.75 & 5.20 & 6.00 & 4.75 & 5.75 & 42.05 \\
$\mathrm{~T}_{3}$ & 5.45 & 7.10 & 6.20 & 6.80 & 5.35 & 6.70 & 5.65 & 5.80 & 49.05 \\
$\mathrm{~T}_{4}$ & 8.60 & 8.30 & 8.70 & 6.35 & 8.40 & 9.05 & 8.10 & 8.60 & 66.10 \\
$\mathrm{~T}_{5}$ & 2.75 & 3.60 & 4.55 & 5.30 & 4.55 & 5.05 & 5.45 & 4.90 & 36.15 \\
$\mathrm{~T}_{6}$ & 5.80 & 5.80 & 5.80 & 4.85 & 5.60 & 4.00 & 5.25 & 5.35 & 42.45 \\
$\mathrm{~T}_{7}$ & 8.00 & 8.70 & 8.00 & 7.50 & 7.65 & 6.65 & 9.10 & 8.55 & 64.15 \\
$\mathrm{~T}_{8}$ & 5.10 & 4.50 & 3.75 & 5.55 & 5.50 & 3.95 & 4.70 & 4.15 & 37.20 \\
$\mathrm{~T}_{9}$ & 3.85 & 3.70 & 3.10 & 3.95 & 3.60 & 3.50 & 3.25 & 2.90 & 27.85 \\
$\mathrm{~T}_{10}$ & 4.40 & 4.40 & 6.10 & 4.25 & 4.20 & 3.60 & 5.20 & 4.65 & 36.80 \\
Kendal's & 0.827 & 0.454 & 0.403 & 0.159 & 0.516 & 0.397 & 0.405 & 0.416 & \\
W test & & & & & & & & & \\
\hline
\end{tabular}

glucose in mango, which absorbed moisture from the environment. Similar trend in moisture content was observed by Mir and Nath (2000) in mango bar enriched with desiccated coconut powder and soy protein concentrate, which contained 18.7 and $18.4 \%$ moisture, respectively. However, Hemakar et al. (2000) evaluated a moisture content of 11.0 per cent in mango bars. Take et al. (2012) also reported moisture content in the range of 14.64-15.91 per cent in fortified sapota-papaya fruit bar. The maximum moisture content in sweet and spiced aonla segments were observed in sucrose treatments, which may be attributed to almost twice the molecular weight of sucrose compared with glucose, which resulted in roughly half the molecular concentration of sucrose solution, and therefore lower osmotic pressure than the glucose solution and thus less water loss (Panagiotou et al., 1999). Garrote and Bertone (1989) also found that glucose and mixture of salt and sucrose improved water loss from fruits.

Titratable acidity (\%): Enrichment of aonla fruit pulp with fruit pulps of mango, papaya and jackfruit resulted in reduction of titratable acidity in all enriched fruit bars as compared to that from pure aonla pulp. It may be due to higher content of TSS and sugars and lower acidity in the pulp of fruits used for enrichment. The treatment $\mathrm{T}_{1}(100 \%$ aonla $)$ recorded highest acidity $(0.313 \%)$ and which was on par with the treatment $\mathrm{T}_{8}(0.297 \%)$ and $\mathrm{T}_{5}(0.296 \%)$ and significantly different from all other treatments and the lowest acidity $(0.15 \%)$ was recorded in $\mathrm{T}_{10}(25 \%$ aonla $+75 \%$ jackfruit). Mishra et al. (2012) recorded $0.4 \%$ titratable acidity in enriched fruit bar from pulp of aonla and guava. Shanthi (2000) reported an acid content of 0.43 per cent in green gram enriched mango bar. Bhardwaj and Mukherjee (2011) observed similar reduction in acidity from 0.72 to $0.51 \%$, when kinnow juice was blended with juice of pomegranate and ginger. Decrease in acidity of aonla juice was also reported by Jain and Khurdiya (2004) when aonla juice was blended with fruit juices of apple, grapes and pomegranate in the preparation of RTS beverages.

Total soluble solids ( $\left.{ }^{\mathbf{0}} \mathbf{B}\right)$ : Enrichment of aonla pulp with fruit pulps of mango, papaya and jackfruit increased the TSS content of fruit bars. The maximum TSS $\left(53.33^{0}\right.$ Brix $)$ was observed in the treatment of $\mathrm{T}_{4}$ $\left(25 \%\right.$ aonla $+75 \%$ mango) while the treatment $\mathrm{T}_{1}$ (100\% aonla) had the minimum TSS $\left(45.23^{\circ}\right.$ Brix). However, the TSS content in all the enriched fruit bars was significantly superior as compared to that of fruit bar from pure aonla. Increase in TSS was reported by Jain and Khurdiya (2004) when aonla juice was blended with fruit juices of apple, grapes and pomegranate in the preparation of RTS beverages. Shanthi (2000) reported a TSS content of $55.0{ }^{0} \mathrm{~B}$ in soy protein enriched mango bar. Bhardwaj and Mukherjee (2011) also reported an increase in TSS when kinnow fruit juice was blended with juice of pomegranate.

Sugars (\%): Blending of aonla pulp with treatments resulted in an increase in reducing, non-reducing and total sugar content of fruit bars. Treatment $\mathrm{T}_{4}(25 \%$ aonla $+75 \%$ mango) had the highest reducing sugar content $(37.80 \%)$ and the lowest $(30.07 \%)$ was in $\mathrm{T}_{1}$ $(100 \%$ aonla $)$. Non reducing sugar content was maximum $(14.84 \%)$ in $\mathrm{T}_{6}(50 \%$ aonla $+50 \%$ papaya $)$ and minimum $(10.30 \%)$ in $\mathrm{T}_{1}(100 \%$ aonla $)$. Blending 25 $\%$ aonla pulp with $75 \%$ jackfruit pulp $\left(\mathrm{T}_{10}\right)$ resulted in maximum total sugars $(50.5 \%)$ and the minimum $(40.24 \%)$ was in fruit bar from pure aonla pulp $\left(\mathrm{T}_{1}\right)$. Mir and Nath (2000) reported a reducing sugar content of 21.8 per cent in mango bar containing desiccated coconut powder. Hemakar et al. (2000) reported a total sugar content of 60.0 per cent in plain mango bar. Increase in total sugar content was also reported by Bhardwaj and Mukherjee (2011) in kinnow juice blended with pomegranate juice. Minimum levels of reducing, non-reducing and total sugars in fruit bar from pure aonla pulp may be due to the naturally low level of sugars in fresh aonla fruit.

Ascorbic acid (mg $100 \mathbf{g ~ g}^{-1}$ ): Ascorbic acid content of fruit bars from aonla showed a declining trend when enriched with fruit pulps of mango, papaya and jackfruit which may be due to the lower initial ascorbic acid content in the pulp of these fruits, as compared to pure aonla pulp. Maximum ascorbic acid content (85.34 mg) was observed in fruit bar from pure aonla 


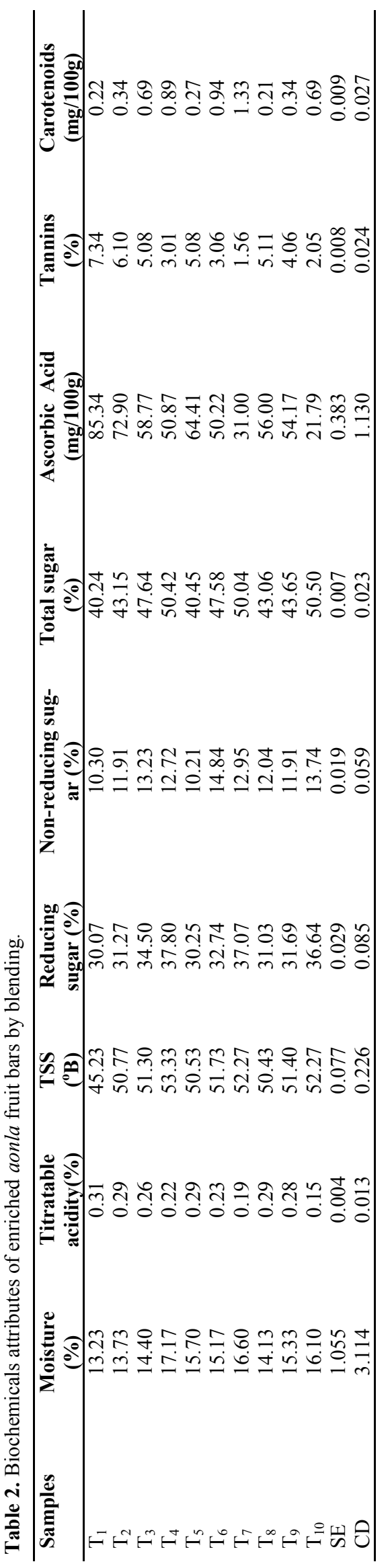

$\left(\mathrm{T}_{1}\right)$, which was significantly higher than that of the enriched fruit bars. Lowest ascorbic acid $(21.79 \mathrm{mg})$ was observed in the treatment $\mathrm{T}_{10}(25 \%$ aonla $+75 \%$ jackfruit). Similar trend in declining of ascorbic acid content was observed in aonla based blended RTS beverages by Jain and Khurdiya (2004). Inyang and Abah (1997) also observed that with increase in proportion of orange juice, the ascorbic acid content of cashew apple juice decreased, when blended with orange juice. Maximum ascorbic acid retention in kinnow juice was reported by Bhardwaj and Mukherjee (2011) when it was blended with aonla juice.

Tannins (\%): Tannin content of enriched fruit bars showed a decreasing trend when aonla pulp was enriched with mango, papaya and jackfruit. Tannin content of fruit bar prepared from pure aonla pulp $\left(\mathrm{T}_{1}\right)$ was the highest $(7.34 \%)$ as compared to all other treatments. Lowest tannin content $(1.56 \%)$ was observed in the fruit bar in which aonla pulp was enriched with $75 \%$ papaya $\left(\mathrm{T}_{7}\right)$. Aonla is not only rich in vitamin $\mathrm{C}$, poly phenols and minerals and also for tannins (Jain and Akhurdiya, 2000) in comparison to other fruits selected in present study. So decline in tannin content may be due to the lower initial tannin content in the pulp of these fruits. Mehta (1995) stated that the total tannins were found to be reduced in the blended pulp with other fruits would have happened as the action of enzyme polyphenoloxidase converting tannin into other products. Reduction in tannin content of cashew apple juice was reported by Inyang and Abah (1997), when it was blended with orange juice. Similar trend in decline of tannin was also observed by Mishra et al. (2012) when pulp of aonla and guava fruits was blended in 50:50 proportion.

Total carotenoids (mg $100 \mathrm{~g} \mathrm{~g}^{-1}$ ): Enrichment of aonla fruit bars with carotenoid rich fruit pulps resulted in an increase in the levels of total carotenoids in the enriched fruit bars which may be due to higher level of carotenoids in these fruits as compared to pure aonla pulp. The increase was significantly superior in all the treatments with increase in the proportion of mango, papaya and jackfruit. Enriched fruit bar containing 25 $\%$ aonla and $75 \%$ papaya pulp $\left(\mathrm{T}_{7}\right)$ had the highest total carotenoids $(1.33 \mathrm{mg})$ was the lowest $(0.21 \mathrm{mg})$ in the fruit bar containing $75 \%$ aonla and $25 \%$ jackfruit pulp $\left(\mathrm{T}_{8}\right)$ which is on par with the fruit bar prepared from pure aonla pulp $\left(\mathrm{T}_{1}\right)$, which contained 0.22 mg of total carotenoids. Similar trend was observed by Mir and Nath (2000) in mango bar enriched with desiccated coconut powder and soy protein concentrate and Shanthi (2000) in mango bar enriched with green gram. Increase in carotenoid content in fortified sapota -papaya fruit bar was reported by Take et al. (2012).

\section{Conclusion}

It has been concluded that blending of aonla pulp with pulp of provitamin A rich fruits viz. mango, papaya 
and jackfruit in different ratios indicated that the initial moisture content was higher $(17.17 \%)$ in aonla pulp enriched with mango pulp in 1:3 proportion. Enrichment also resulted in an increase in TSS $\left(45.23^{\circ}\right.$ Brix to $\left.53.33^{0} \mathrm{Brix}\right)$, reducing $(30.07 \%$ to $37.80 \%)$, nonreducing (10.30\% to $14.84 \%)$ and total sugars $(40.24 \%$ to $50.50 \%$ ) of the resultant fruit bars from pure aonla pulp, may be due to the naturally low level of sugars in fresh aonla fruit Fruit bars prepared from aonla pulp enriched with pulp of fruits containing provitamin A, showed a rise in total carotenoids $(0.21 \mathrm{mg} / 100 \mathrm{gm}$ to $1.33 \mathrm{mg} / 100 \mathrm{gm})$, the increase being higher with greater proportion of the pulp of these fruits. Enrichment of aonla pulp with fruit pulp of mango, papaya and jackfruit reduced the titratable acidity, ascorbic acid (85.34 $\mathrm{mg} / 100 \mathrm{gm}$ to $21.79 \mathrm{mg} / 100 \mathrm{gm}$ ) and tannin content $(7.34 \%$ to $1.56 \%)$ of the resultant enriched fruit bars as compared to that from pure aonla pulp, due to the lower initial tannin content in the pulp of these fruits as compared with aonla, which is an indication in the reduction of astringency Enrichment of aonla pulp with fruit pulp of mango and papaya significantly improved acceptability with increasing proportion of these fruits. However, a reverse trend was observed when aonla was blended with jackfruit. Of all the treatments, enriched fruit bar containing $25 \%$ aonla and $75 \%$ mango $\left(\mathrm{T}_{4}\right)$ had higher acceptability score. Enrichment of aonla pulp with mango and papaya resulted in enhanced acceptability of the fruit bar.

\section{REFERENCES}

Ahmad, J., Mehmood, Z. and Mohammad, F. (1998). Screening of some Indian medicinal plants for their antimicrobial properties. Journal of Ethanopharmacology. 62: 183-193

Amerine, M. A., Pangborn, R. N. and Rossler, E. B. (1965). Principles of sensory evaluation of food. In: Food Science and Technology Monographs. pp.338-339. Academic Press, New York.

AOAC, (1990). Official methods of analysis. - 13th ed. Association of Official Analytical Chemist Benjamin Franklin Station, Washington D.C., USA.

Bhardwaj, R. and Mukherjee, S. (2011). Effect of fruit juice blending ratios on kinnow juice preservation at ambient storage condition. J. Food Sci. Technol., 5 (5): 281-286.

Bhosale, V.I., Kute, L.S. and Kadam, S.S. (2000). Studies on preparation of ready to serve beverage from aonla: mango juice blend. Bev Food World., 27(2): 24-27

Duncan, D. B. (1955). Multiple range and multiple F-Test. Biometrics, 11: 1-42

Garrote, R.L. and Bertone, R.A. (1989). Osmotic concentration at low temperature of frozen strawberry halves: Effect of glycerol, glucose and sucrose solutions on exudates loss during thawing. Lebensmittel Wissenschafyt und Technologie, 22: 264-267

Hemakar, A.K., Tomar, M.C. and Singh, U.B. (2000). Studies on blending of guava pulp with mango pulp for dehydration (mango-guava sheet). Indian Food Packer, 54: $45-48$

Inyang, U. E. and Abah, U. J. (1997). Chemical composition and organoleptic evaluation of juice from steamed cashew apple blended with orange juice. Plant Food Human Nutr., 50 (4): 295-300

Jain, S.K. and Akhurdiya, D.S. (2000). Anola: potential fruit for processing. Delhi Garden Mega., 38: 50-51.

Jain, S.K. and Khurdiya, D.S. (2002). Physicochemical characteristics and postharvest technology of aonla (Phyllanthus emblica L.) - a resume. Indian Food Packer, 47: 46-49

Jain, S.K. and Khurdiya, D.S. (2004). Vitamin C enrichment of fruit juice based Ready-to-Serve beverages through blending of Indian goosebery (Emblica officinalis Gaertn.) juice. Plant Food Human Nutr., 59: 63-66

Jose, J.K., Kuttan, Y. and Kutan, R. (2001). Antitumour activity of Emblica officinalis. Journal of Ethanopharmacology, 75: 65-69

Kadam, S.S. (2001). New products from the arid and semiarid fruits. Indian J. Hortic., 58 (2): 170-177

Khopde, S.M., Indira, P.K. and Mohan, H. (2001). Characterizing the antioxidant activity of amla (Phyllanthus emblica) extract. J. Food Sci., 81: 185-190

Kirtikar, K.R. and Basu, B.D. (1993). Indian Medicinal Plants. $2^{\text {nd }}$ (Ed.) 3: 2343, Delhi, India.

Mehta, S. (1995). Evaluation of different cultivars of aonla (Emblica officinalis Garten)) for processing. [M.Sc. Thesis]. Chaudhary Charan Singh Haryana Agricultural University. Hisar.

Mir, M. A. and Nath, N. (2000). Protein fortification of mango bar using soy protein concentrate and coconut powder. J. Food Sci. Technol., 37: 528-529

Mishra, V., Puranik, V., Yadav, N. and Rai, G.K. (2012). Bioactive components retention in processed Indian Gooseberry products. J. Food Sci. Technol., 3: 12

Panagiotou, N.M., Karathanos, V.T. and Maroulis, Z.B. (1999). Effect of osmotic agent on osmotic dehydration of fruits. Drying Technology, 17(1\&2): 175-189

Panse, V.G. and Sukhatme, D.V. (1976). Statistical methods for Agricultural Workers. Indian Council of Agricultural Research, New Delhi, 36p.

Ranganna, S. (1997). Handbook of Analysis and Quality Control for Fruit and Vegetable Products $\left(2^{\text {nd }} E d\right)$. Tata McGraw Hill Pub. Company Limited, New Delhi. $1112 \mathrm{p}$.

Ranganna, S. (2000). Handbook of Analysis of Quality control for Fruit and Vegetables Products. $2^{\text {nd }}$ ed. Tata Mcgraw Hill Pub. Co. New Delhi. p. 84-88; 182-189

Sairam, K., Rao, Ch. V., Dora Babu, M., Vijay Kumar, K., Agrawal, V.K. and Goel, R.K. (2002). Anti-ulcerogenic effect of methanolic extract of Emblica officinalis: an experimental study. Journal of Ethanopharmacology, 82: $1-9$

Shanthi, K.P. (2000). Storage stability of protein enriched mango bars in different packaging materials. M.Sc. (Home science) Thesis, T.N.A.U., Madurai. 112p.

Singh, S., Singh, A.K. and Joshi, H.K. (2006). Standardization of maturity indices in Indian gooseberry (Emblica officinalis Gaertn) under semiarid conditions of Gujarat. Indian J Agr Sci., 76:591-595

Take, M.A., Bhotmange, G.M. and Shastri, P.N. (2012). Studies on preparation of fortified sapota-papaya fruit bar. J. Nutr. Food Sci., 2: 6

Tandon, D.K., Kumar, S. and Dikshit, A. (2003). Improvement in technology for production of amla suparis. Processed Food Ind., 6: 23-24 